\title{
High levels of polymorphism found through cross-amplification of microsatellite loci in a Ctenomys pearsoni (Rodentia, Ctenomyidae) population
}

\author{
N. Mannise ${ }^{1}$, S. González ${ }^{1}$, J.E. Maldonado ${ }^{2,3}$, G. Izquierdo ${ }^{4}$, \\ G. Francescoli ${ }^{4}$ and M. Cosse ${ }^{1}$ \\ ${ }^{1}$ Genética de la Conservación, Departamento de Genética, \\ Instituto de Investigaciones Biológicas Clemente Estable, \\ Unidad Asociada Facultad de Ciencias, Universidad de la República, \\ Montevideo, Uruguay \\ ${ }^{2}$ Center for Conservation and Evolutionary Genetics, \\ Smithsonian Conservation Biology Institute, National Zoological Park, \\ Washington, DC, USA \\ ${ }^{3}$ Department of Vertebrate Zoology, National Museum of Natural History, \\ Smithsonian Institution, Washington, DC, USA \\ ${ }^{4}$ Sección Etología, Instituto de Biología, \\ Facultad de Ciencias, Universidad de la República, Montevideo, Uruguay \\ Corresponding author: M. Cosse \\ E-mail: mcosse@iibce.edu.uy
}

Genet. Mol. Res. 12 (2): 887-891 (2013)

Received June 4, 2012

Accepted January 1, 2013

Published April 2, 2013

DOI http://dx.doi.org/10.4238/2013.April.2.5

\begin{abstract}
Ctenomys pearsoni (Pearson's tuco-tuco) is a subterranean rodent native to Uruguay. We tested the amplification pattern of 12 microsatellite loci, designed for C. sociabilis and C. haigi in a $C$. pearsoni population. DNA extractions were made from hair samples, and PCR amplification products were run on an ABI 3100 microcapillary gel. Eight loci were selected to form a highly polymorphic panel that could be used to efficiently screen populations of this species. In
\end{abstract}


DNA from 35 tuco-tucos, the mean polymorphic information content value was 0.6536 and the mean expected heterozygosity was 0.7166 . Paternity non-exclusion probabilities for seven independent loci were $\mathrm{NE}-1 \mathrm{P}=0.0766$ and NE-2P $=0.0108$, and combined non-exclusion $\mathrm{P}(\mathrm{ID})$ was $6.2 \times 10^{-7}$. This panel of microsatellite loci has sufficient power to make inferences regarding group structure, mating strategies and evolutionary relationships among populations.

Key words: Subterranean rodents; Rodentia: Ctenomyidae; Caviomorpha; Nuclear short tandem repeats

\section{INTRODUCTION}

The Ctenomyidae (tuco-tucos) are subterranean rodents that have undergone explosive karyotypic radiation. This group has a large number of species with chromosome numbers ranging from $2 \mathrm{n}=10$ to $2 \mathrm{n}=70$ (Reig et al., 1990; Lessa and Cook, 1998; Lacey et al., 2000). Ctenomys pearsoni is 1 of 3 species of ctenomyids found in Uruguay (Lessa and Langguth, 1983). It mainly inhabits coastal sandy areas or dunes, although individuals have been found living as far as $500 \mathrm{~m}$ from sandy soil (Altuna et al., 1999). Typically, these animals prefer living along the banks or near the mouths of rivers (Altuna, 1983; Lessa and Langguth, 1983; Altuna et al., 1999). Moreover, this species is characterized by having the highest levels of karyotypic variation at intra- and inter-population levels (Reig et al., 1990; Novello et al., 1990, 1996; Villar et al., 2005) that is incongruent with the low levels of morphological and molecular variation observed among populations (D'Anatro and D'Elía, 2011).

Despite the peculiar genetic characteristics of this species, no population genetic studies using hypervariable nuclear loci have been conducted to date. Microsatellites are widely used in studies of population genetic structure because they have high levels of intraspecific variability and high-resolution power in complex evolutionary scenarios (Lacey et al., 1999; Kays et al., 2000; Cosse et al., 2007).

Microsatellite loci previously isolated and characterized for Ctenomys sociabilis and C. haigi (Lacey et al., 1999; Lacey, 2001) have been used to determine genetic population structure, phylogeography, relatedness and dispersal patterns in several species of this genus (Lacey, 2001; Parada, 2003; Wlasiuk et al., 2003; El Jundi and De Freitas, 2004; Cutrera et al., 2005; Fernandes et al., 2007; Mora et al., 2007). Several studies have taken advantage of the relatively highly conserved microsatellite flanking regions in related species (Wlasiuk et al., 2003; El Jundi and De Freitas, 2004; Cutrera et al., 2005; Cosse et al., 2007). The aim of this study was to test 12 microsatellite loci isolated from C. sociabilis and C. haigi to characterize a set of highly polymorphic microsatellite loci in C. pearsoni.

\section{MATERIAL AND METHODS}

\section{Samples}

Samples were collected in a C. pearsoni population located in Estancia El Relincho, Departamento de San José, in southwestern Uruguay ( $\left.34^{\circ} 20^{\prime} \mathrm{S}, 56^{\circ} 58^{\prime} \mathrm{W}\right)$. A clump of ap- 
proximately 20 hair samples was taken from each of the 35 animals captured. Captures were carried out using Oneida Victor $\mathrm{N}^{\circ} 0$ traps located inside the tunnels after opening one of the burrow entrances. Traps were softened with rubber and polyurethane foam to avoid harming the animals and were checked every 10 min to avoid injuries when captured animals tried to escape the trap.

\section{DNA extraction and polymerase chain reaction (PCR)}

DNA was extracted from hair samples following a procedure described by González et al. (1998). PCR was conducted in $10-\mu \mathrm{L}$ reactions containing $10 \mathrm{ng}$ DNA, $0.2 \mu \mathrm{M}$ of each primer (forward and reverse), $0.2 \mathrm{mM}$ deoxyribonucleotide triphosphate, $1 \mathrm{X}$ Taq buffer with $\mathrm{KCl}, 2.5 \mathrm{mM} \mathrm{MgCl}, 0.5 \mu \mathrm{g} / \mu \mathrm{L}$ bovine serum albumin, and $0.75 \mathrm{U}$ Taq polymerase (Fermen$\operatorname{tas}^{\circledR}$, Thermo Scientific Inc., Vilnius, Lithuania). The profile used consisted of $94^{\circ} \mathrm{C}$ for $5 \mathrm{~min}$, followed by 34 cycles of $94^{\circ} \mathrm{C}$ for $30 \mathrm{~s}$, annealing temperatures for $30 \mathrm{~s}$, and $72^{\circ} \mathrm{C}$ for $45 \mathrm{~s}$, with a final extension of $72^{\circ} \mathrm{C}$ for $5 \mathrm{~min}$. Locus-specific annealing temperatures ranged from $56^{\circ}$ to $62^{\circ} \mathrm{C}$ (Lacey et al., 1999; Lacey, 2001) and fluorochrome labels were FAM, HEX, or TET. To confirm amplification, a volume $(4 \mu \mathrm{L})$ of each product was electrophoresed on a $2 \%$ SbS - Besta ${ }^{\mathrm{TM}}$ Agarose gel (SBS Genetech Co. Ltd., Beijing, China) for $180 \mathrm{~min}$. Amplified products were run with a LIZ 500 size standard on an $\mathrm{ABI} 3130^{\circledR}$ automated sequencer. Migration was performed in a 36-cm capillary array using POP7 polymer (Applied Biosystems, USA) with the following parameters: $50 \mathrm{~mA}, 15 \mathrm{kV}$, and $60^{\circ} \mathrm{C}$ for $1200 \mathrm{~s}$.

\section{Genotyping and microsatellite locus characterization}

Genotyping and fragment size analysis were conducted using the GeneMarker ${ }^{\circledR}$ software (Softgenetics ${ }^{\circledR}$ Inc.). We calculated observed and expected values of heterozygosity and tested for Hardy-Weinberg equilibrium (HWE) and linkage disequilibrium (LD) using GENEPOP $^{\circledR}$ (Raymond and Rousset, 1995). Polymorphic information content (PIC), paternity non-exclusion probability (NE-1P, NE-2P), and combined non-exclusion probability for identity were estimated with Cervus 3.0. (Marshall et al., 1998).

\section{RESULTS}

Of the 12 microsatellite loci tested, 4 loci that gave poor amplification success or low polymorphism levels were discarded. The 8 remaining polymorphic loci were then screened for LD between pairs of loci. This test revealed significant results in 2 comparisons - Hai4Hai9 $(\mathrm{P}=0.0425)$ and Hai4-Hai12 $(\mathrm{P}=0.0462)$ - and the remaining loci were considered to be independent. For this reason, the Hai4 locus was excluded from the analysis. After Bonferroni's correction for multiple comparisons, none of the loci showed significant deviations from HWE (Table 1).

Allelic diversity of microsatellites across loci ranged from 4 to 8 alleles/locus (mean $=$ 5.8; see Table 1). Mean expected heterozygosity and PIC of the seven loci in linkage equilibrium were 0.7166 and 0.6536 , respectively. Paternity non-exclusion probabilities for these loci were NE- $1 \mathrm{P}=0.0766$ and NE-2P $=0.0108$. Combined non-exclusion probability for identity was $6.2 \times 10^{-7}$ (see Table 1$)$. 
Table 1. Number of individuals analyzed $(\mathrm{N})$, number of alleles $\left(N_{\mathrm{A}}\right)$ and their range of size [S (bp)], polymorphism information content (PIC) values, non-exclusion probabilities for the first (NE-1P) and second (NE-2P) parent, non-exclusion probability for the identity [P(ID)], observed and expected heterozygosity $\left(H_{\mathrm{O}}\right.$ and $H_{\mathrm{E}}$, respectively), and $\mathrm{P}$ values calculated for the Hardy-Weinberg test for heterozygote deficiency in the 7 loci in linkage equilibrium.

\begin{tabular}{|c|c|c|c|c|c|c|c|c|c|c|}
\hline Locus & $\mathrm{N}$ & $\mathrm{S}(\mathrm{bp})$ & $N_{\mathrm{A}}$ & $H_{\mathrm{O}}$ & $H_{\mathrm{E}}$ & PIC & NE-1P & NE-2P & $\mathrm{P}(\mathrm{ID})$ & $\mathrm{P}$ \\
\hline Soc $1^{\mathrm{a}}$ & 35 & $269-279$ & 6 & 0.600 & 0.709 & 0.653 & 0.713 & 0.539 & 0.137 & 0.9101 \\
\hline Soc $2^{\mathrm{a}}$ & 34 & $135-161$ & 4 & 0.618 & 0.629 & 0.554 & 0.803 & 0.654 & 0.211 & 0.9857 \\
\hline Soc $3^{\mathrm{a}}$ & 30 & $112-134$ & 6 & 0.867 & 0.783 & 0.735 & 0.621 & 0.442 & 0.088 & 0.8749 \\
\hline Soc $5^{\mathrm{a}}$ & 33 & $260-272$ & 7 & 0.788 & 0.686 & 0.622 & 0.740 & 0.574 & 0.158 & 0.7044 \\
\hline Soc $6^{\mathrm{a}}$ & 35 & $215-221$ & 4 & 0.543 & 0.600 & 0.506 & 0.818 & 0.693 & 0.252 & 0.0712 \\
\hline Hai $9^{b}$ & 20 & $221-235$ & 6 & 0.700 & 0.800 & 0.745 & 0.610 & 0.431 & 0.083 & 0.1131 \\
\hline Hai $12^{b}$ & 22 & $112-136$ & 8 & 0.682 & 0.809 & 0.761 & 0.584 & 0.406 & 0.074 & 0.4109 \\
\hline Hai $4^{b}$ & 34 & $166-182$ & 6 & 0.706 & 0.766 & 0.718 & 0.641 & 0.462 & 0.097 & 0.2923 \\
\hline
\end{tabular}

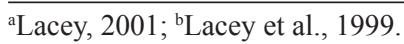

\section{DISCUSSION}

Although this analysis was performed in a small population of C. pearsoni, the 8 loci screened proved to have sufficiently high levels of polymorphism and heterozygosity to conduct a relatedness analysis. Values obtained with this set of loci for combined probabilities of non-exclusion for the parents (NE-1P, NE-2P) and combined probability of non-exclusion for identity proved to be highly reliable when assigning paternity. In addition to enabling relatedness inferences between individuals, this panel of microsatellite loci had enough power to elucidate the levels of genetic structure of the population.

\section{ACKNOWLEDGMENTS}

We thank Mónica Rumbo, Noelia Zambra, Erika Görke, Yennifer Hernández, Noelia Kandratavicius, Martín Petrella, Micaela Trimble, and Lorena Coelho for field support; Guillermo Macció and workers at El Relincho, who kindly provided logistic assistance and housing during fieldwork; Ivanna Tomasco and the Laboratorio de Evolución (Facultad de Ciencias, Universidad de la República, Uruguay) for help in obtaining primers, and Guillermo D'Elia and Matias Mora for their suggestions. Research supported by Comisión Sectorial de Investigación Científica (Universidad de la República, Uruguay).

\section{REFERENCES}

Altuna CA (1983). Sobre la estructura de las construcciones de Ctenomys pearsoni Lessa y Langguth, 1983 (Rodentia, Octodontidae). Res. Com. Jorn. C. Nat. Monte-video 3: 70-72.

Altuna CA, Francescoli G, Tassino B and Izquierdo G (1999). Ecoetología y conservación de mamíferos subterráneos de distribución restringida: el caso de Ctenomys pearsoni (Rodentia, Octodontidae) en el Uruguay. Etología 7: 47-54.

Cosse M, González S and Maldonado JE (2007). Cross-amplification tests of ungulate primers in the endangered Neotropical pampas deer (Ozotoceros bezoarticus). Genet. Mol. Res. 6: 1118-1122.

Cutrera AP, Lacey EA and Busch C (2005). Genetic structure in a solitary rodent (Ctenomys talarum): implications for kinship and dispersal. Mol. Ecol. 14: 2511-2523.

D'Anatro A and D'Elía G (2011). Incongruent patterns of morphological, molecular, and karyotypic variation among populations of Ctenomys pearsoni (Rodentia, Ctenomyidae). Mamm. Biol. 76: 36-40.

El Jundi TA and De Freitas TR (2004). Genetic and demographic structure in a population of Ctenomys lami (RodentiaCtenomyidae). Hereditas 140: 18-23. 
Fernandes FA, Fernández-Stolz GP, Lopes CM and Freitas TR (2007). The conservation status of the tuco-tucos, genus Ctenomys (Rodentia: Ctenomyidae), in southern Brazil. Braz. J. Biol. 67: 839-847.

González S, Maldonado JE, Leonard JA, Vilà C, et al. (1998). Conservation genetics of the endangered Pampas deer (Ozotoceros bezoarticus). Mol. Ecol. 7: 47-56.

Kays RW, Gittleman JL and Wayne RK (2000). Microsatellite analysis of kinkajou social organization. Mol. Ecol. 9: 743-751.

Lacey EA (2001). Microsatellite variation in solitary and social tuco-tucos: molecular properties and population dynamics. Heredity 86: 628-637.

Lacey EA, Maldonado JE, Clabaugh JP and Matocq MD (1999). Interspecific variation in microsatellites isolated from tuco-tucos (Rodentia: Ctenomyidae). Mol. Ecol. 8: 1754-1756.

Lacey EA, Patton JL and Cameron GN (2000). Introduction. In: Life Underground: The Biology of Subterranean Rodents (Lacey EA, Patton JL and Cameron GN, eds.). University of Chicago Press, Chicago, 1-14.

Lessa EP and Langguth A (1983). Ctenomys pearsoni, n. sp. (Rodentia, Octodontidae), del Uruguay. Res. Com. Jorn. C. Nat. Monte-video 3: 86-88.

Lessa EP and Cook JA (1998). The molecular phylogenetics of tuco-tucos (genus Ctenomys, Rodentia: Octodontidae) suggests an early burst of speciation. Mol. Phylogenet. Evol. 9: 88-99.

Marshall TC, Slate J, Kruuk LE and Pemberton JM (1998). Statistical confidence for likelihood-based paternity inference in natural populations. Mol. Ecol. 7: 639-655.

Mora MS, Lessa EP, Cutrera AP, Kittlein MJ, et al. (2007). Phylogeographical structure in the subterranean tuco-tuco Ctenomys talarum (Rodentia: Ctenomyidae): contrasting the demographic consequences of regional and habitatspecific histories. Mol. Ecol. 16: 3453-3465.

Novello A, Lessa EP, Sambarino C and Monzón S (1990). Chromosomal variation in two populations of the genus Ctenomys (Rodentia, Octodontidae) from Uruguay. Z. Säugertierkunde 55: 43-48.

Novello A, Cortinas MN, Suárez M and Musto H (1996). Cytogenetic and molecular analysis of the satellite DNA of the genus Ctenomys (Rodentia Octodontidae) from Uruguay. Chromosome. Res. 4: 335-339.

Parada A (2003). Análisis de Parentesco Dentro de Una Población de Ctenomys rionegrensis (Rodentia: Octodontidae) Polimórfica en el Color de Pelaje, Empleando Microsatélites. Master's thesis, Facultad de Ciencias, Universidad de la República, Montevideo.

Raymond M and Rousset F (1995). An exact test for population differentiation. Evolution 49: 1280-1283.

Reig O, Busch C, Ortells MO and Contreras JR (1990). An Overview of Evolution, Systematics, Population Biology and Speciation in Ctenomys. In: Evolution of Subterranean Mammals at the Organismal and Molecular Levels (Nevo E and Reig OA, eds.). Alan R. Liss, New York, 71-96.

Villar S, Martínez W, Folle G and Novello A (2005). Cytogenetic analysis of different Ctenomys (Rodentia, Octodontidae) species from Uruguay using G-banding. Mamm. Biol. 70: 255-270.

Wlasiuk G, Garza JC and Lessa EP (2003). Genetic and geographic differentiation in the Rio Negro tuco-tuco (Ctenomys rionegrensis): inferring the roles of migration and drift from multiple genetic markers. Evolution 57: 913-926. 